\title{
$\mathrm{H}$ 병원 치과응급실에 내원한 치아 외상 환자에 대한 임상적 \\ 고찰
}

안소연 · 김아현 ${ }^{1} \cdot$ 심연수 $^{2}$

원광대학교 치과대학 산본치과병원 소아치과 $\cdot{ }^{1}$ 연세대학교 치과대학 예방치과학교실 - ${ }^{2}$ 청주대학교 치위생학과

\section{Dental trauma patients visiting the emergency room in $\mathrm{H}$ hospital}

\author{
So-Youn An • Ah-Hyeon $\mathrm{Kim}^{1} \cdot$ Youn-Soo Shim ${ }^{2}$
}

Department of Pediatric Dentistry, College of Dentistry, Wonkwang University, Sanbon Hospital $\cdot{ }^{1}$ Department of Preventive Dentistry \& Public Oral Health, College of Dentistry, Yonsei University $\cdot{ }^{2}$ Department of Dental Hygiene, Cheongju University

Received : 10 July, 2013
Revised : 10 October, 2013
Accepted : 10 October, 2013
Corresponding Author
Youn-Soo Shim
Department of Dental Hygiene
College of Health Science, Cheongju
University 298 Daeseong-ro
Sangdang-gu, Cheongju-si
Chungcheongbuk-do, 360-764, Korea.
Tel : + 82-31-229-8351
$\quad+82-10-3404-2171$
Fax : + 82-43-229-8969
E-mail : shim-21@hanmail.net

\section{서론}

현대인의 생활양식과 환경이 도시화되고 취미활동이 다양 화됨에 따라 외상을 받을 수 있는 요인들이 증가하고, 특히 소아청소년의 경우 활동량의 증가로 외상의 기회가 많아지고 있다. 지난 10-20년간 외상의 발병률은 점차 증가하였으며, 소아청소년의 치아우식증이나 치주질환의 발생률을 능가할 것이라고 예상하고 있다 ${ }^{1)}$. 영국에서는 우식 발생률은 감소한

\section{ABSTRACT}

Objectives : The purpose of this study was to analyze the types of dental emergencies. This study was carried out for dental trauma patients visiting the emergency room in $\mathrm{H}$ hospital from 2005 to 2006

Methods : Subjects were 252 patients. Demographic characteristics consisted of age, gender, dentition, and dental related injury.

Results : Male patients had 1.65 times higher tooth injury than female. Teenagers had higher prevalence of tooth injury. Main cause of dental injury was falling down. Young children accounted for $41.7 \%$ of the injuries. Late evening was the highest outbreak time of injury. The most commonly affected teeth were central incisor and lateral incisor. The damage of oral soft tissue was more common than the that of alveolar bone. Main area of primary tooth loss was gingiva(10.7\%), tongue or soft palate(7.5\%), and frenulum(6.0\%). Subluxation(28.6\%) and luxation(28.6\%) were main cause for the primary teeth. Tooth fracture $(50.0 \%)$ were the most common injury.

Conclusions : Thus, to understand the incidence, causes and patterns of dental trauma is to help preserving natural teeth. The results of this study could provide the clinical guidelines on the treatment of dental emergency patients.

Key Words : dental emergency room, dental injury, dental trauma, emergency medical service 색인 : 응급의료, 치과 응급실, 치아 손상, 치아 외상 
었다 ${ }^{4)}$. 이를 2003년 국민구강건강실태조사 결과에서는 악안 면 외상 경험 비율이 전체 대상자의 9.42\%(남자는 $11.89 \%$, 여자는 $6.96 \%)$ 이었고 ${ }^{5}, 2006$ 년 조사 결과에서는 대상자의 $16.4 \%$ (남자는 $22.4 \%$, 여자는 $10.7 \%$ )이었던 것 ${ }^{6}$ 과 비교해 볼 때, 최근에 지속적으로 증가되고 있는 추세이다.

외상 치아의 $\mathrm{WHO}$ 분류로는 크게 파절(골절) 손상과 변위 손상으로 나누어진다. 파절 손상은 크게 잇몸 밖에 노출되어 있는 치관파절과 잇몸 안쪽의 치근파절, 그리고 파절선이 두 부위를 모두 침범하는 치관-치근파절로 분류된닥. 변위 손 상은 치아자체에는 파절선이 없이 치조와로부터 치아가 분리 된 손상으로 진탕, 아탈구, 탈구, 정출, 함입이 이에 속한다. 이중 치근 파절, 치조돌기 골절을 제외하곤 모두 이학적 검사 를 통해 진단 할 수 있다고 하였닥.

치아외상은 응급의료기관을 방문하는 흔한 원인 중 하나로 서, 응급실을 통해 내원하는 치과환자는 외상뿐만 아니라 급 성 치통, 출혈, 감염 등 다양한 치과 질환을 주소로 하고 있다. 치과 응급환자의 경우 생명을 위협 받는 경우는 드물지만 응급 질환의 1 차적인 처치는 예후에 결정적인 영향을 미칠 수 있다 ${ }^{8)}$. Petersson 등"은 특히나 구강영역에서의 외상은 10 세 이전에 가장 많이 발생하고 나이가 증가함에 따라 점점 감소하며 30대 이후에는 드물게 발생하며, 구강악안면 부위 의 외상의 발생이 성장과 발육이 진행 중인 어린 나이에 집중 되는 경향이 크다고 하였다.

외상은 연령, 손상의 종류와 정도 및 외상 후 치료 전까지의 경과시간 등이 치료에 영향을 줄 수 있는 요인으로서 이러한 요인들을 분석하여 외상에 대한 예방, 적절한 처치 및 보호자 교육 등에 사용 될 수 있는 지침이 필요하나 현재는 그에 대한 자료가 부족한 실정이다.

따라서 본 연구에서는 2 년간 응급실에 내원한 치과 환자에 대한 연구를 통하여 치과 외상 환자의 유형을 이해하며 적절 한 진단과 처치에 도움을 얻고자 이 연구를 진행하였다.

\section{연구대상 및 방법}

\section{1. 연구대상}

2005년 1월부터 2006년 12월까지 2년간 H병원 응급실에 내원한 환자 중 야간에 치과에서 응급진료를 받은 환자 252명 을 대상으로 선정하였다.

\section{2. 연구방법}

모든 대상자들의 내원 당시 의무기록지 내용과 임상소견을 기초로 하여 외상 환자의 연령, 성별, 치열, 손상 원인, 손상 시기, 동반 손상 유무, 외상 시 손상 치아의 위치 및 개수, 손상 유형에 대한 검사를 시행하였다.

\section{3. 통계분석}

수집한 자료는 발생시간, 외상발생치아의 위치, 외상 시 동반손상 여부 분석은 백분율로, 성별, 연령별, 치열별을 위 하여 백분율과 카이스퀘어 분석을 실시하였다. 성별, 연령 별, 치열별, 치아위치에 따른 외상발생원인에 대하여 교차표 를 이용한 카이스퀘어분석을 실시하였고, 손상유형별 치아 개수, 치열에 따른 치아외상의 유형은 교차표를 이용한 카이 스퀘어 분석을 실시하였다. 모든 자료의 통계처리는 PASW statistics 18.0 프로그램(IBM Co., Armonk, NY, USA)을 이용 하였다.

\section{연구성적}

\section{1. 내원 환자의 연령에 따른 성별, 치열별 구강 악안면부 외상발생 분포}

내원 환자 252 명 중 남자는 $62.3 \%$, 여자는 $37.7 \%$ 으로 남자 가 여자보다 1.65 배 많은 외상을 경험했다. 그리고 연령별 분포에서는 0 세 이하가 $43.7 \%$ 으로 가장 큰 비중을 차지했고,

Table 1. Table 1. Age, sex and dentition distribution of patients with trauma

Unit: N(\%)

\begin{tabular}{lrrrrrr}
\hline \multirow{2}{*}{ Age } & \multicolumn{5}{c}{ Sex } & \multicolumn{2}{c}{ Dentition $^{*}$} & \multirow{2}{*}{ p } \\
\cline { 2 - 5 } & Male & Female & \multicolumn{1}{c}{ Total } & Primary & Permanent $^{*}$ & \\
\hline $0-10$ & $58(36.9)$ & $52(54.7)$ & $110(43.7)$ & $42(100.0)$ & $23(15.6)$ & \\
$11-20$ & $19(12.1)$ & $10(10.5)$ & $29(11.5)$ & $0(0.0)$ & $25(17.0)$ & \\
$21-30$ & $22(14.0)$ & $8(8.4)$ & $30(11.9)$ & $0(0.0)$ & $27(18.4)$ & \\
$31-40$ & $23(14.6)$ & $10(10.5)$ & $33(13.1)$ & $0(0.0)$ & $31(21.1)$ & \\
$41-50$ & $22(14.0)$ & $2(2.1)$ & $24(9.5)$ & $0(0.0)$ & $20(13.6)$ & \\
$\geq 51$ & $13(8.3)$ & $13(13.7)$ & $26(10.3)$ & $0(0.0)$ & $21(14.3)$ & \\
Total & $157(62.3)$ & $95(37.7)$ & $252(100.0)$ & $42(100.0)$ & $147(58.3)$ & \\
\hline
\end{tabular}

Primary and permanent dentition were written only when the injury 
Table 2. Causes of injuries according to age

\begin{tabular}{|c|c|c|c|c|c|c|c|c|}
\hline \multirow[b]{2}{*}{ Age } & \multicolumn{8}{|c|}{ Causes of injuries } \\
\hline & $\begin{array}{c}\text { Traffic } \\
\text { accident }\end{array}$ & Fall down & Sports & Fight & Others* & Total & $x^{2}$ & $p$ \\
\hline $0-10$ & $12(10.9)$ & $57(51.8)$ & $0(0.0)$ & $0(0.0)$ & $41(37.3)$ & $110(43.7)$ & & 0.00 \\
\hline $11-20$ & 2(6.9) & $8(27.6)$ & $0(0.0)$ & $8(27.6)$ & $11(37.9)$ & 29(11.5) & & \\
\hline $21-30$ & $5(16.7)$ & 10(33.3) & $0(0.0)$ & $10(33.3)$ & $5(16.7)$ & 30(11.9) & & \\
\hline $31-40$ & $5(15.2)$ & $10(30.3)$ & $0(0.0)$ & 11(33.3) & $7(21.2)$ & $33(13.1)$ & 74.228 & \\
\hline $41-50$ & $4(16.7)$ & $6(25.0)$ & $2(8.3)$ & 8(33.3) & $4(16.7)$ & $24(9.5)$ & & \\
\hline$\geq 51$ & $2(7.7)$ & $14(53.8)$ & $0(0.0)$ & $7(26.9)$ & $3(11.5)$ & 26(10.3) & & \\
\hline Total & $30(11.9)$ & $105(41.7)$ & $2(0.8)$ & $44(17.5)$ & $71(28.2)$ & $252(100.0)$ & & \\
\hline
\end{tabular}

"Others include the collision

남자,여자 모두 10 대에 가장 높은 치아 외상 경험을 보였다. 유치열과 영구치열은 손상이 있는 경우만 본 결과 유치열보 다는 영구치열에서 높은 외상발생을 보였다〈Table 1〉.

\section{2. 연령별 구강악안면부 외상발생원인}

구강악안면부 외상 발생 원인에 대한 분포는 연령에 따라 통계적으로 유의한 차이가 있었다 $\left(\chi^{2}=74.228, \mathrm{p}<0.00\right)$. 전체 252 건 중 낙상(41.7\%), 기타(28.2\%), 싸움(17.5\%), 교통사고 $(11.9 \%)$, 운동 $(0.8 \%)$ 의 순위로 외상이 발생하였다. 10 세 이하 에서는 낙상 $(51.8 \%), 51$ 세 이상에서도 낙상(53.8\%)의 비율이 높았고, 그 외의 연령에서는 싸움의 비율이 높았다〈Table 2〉.

\section{3. 치열별 외상발생원인}

구강악안면부 외상 발생 원인에 대한 분포는 치열에 따라 통계적으로 유의한 차이가 있었다(유치열 $\chi^{2}=11.605, \mathrm{p}\langle 0.05$, 영구치열 $\left.\chi^{2}=36.486 \mathrm{p}<0.00\right)$. 유치열과 영구치열 모두에서 낙상에 의한 외상의 발생의 비율이 높았다〈Table 3 〉.

\section{4. 위치별 구강악안면부 외상발생원인}

구강악안면부 외상 발생 원인에 대한 분포는 위치에 따라 통계적으로 유의한 차이가 있었다(상악 $\chi^{2}=14.596, \mathrm{p}<0.05$, 하악 $\chi^{2}=19.110 \mathrm{p}\langle 0.05)$. 상악에서는 낙상(38.5\%), 하악에서 는 싸움(35.7\%)에 의한 외상의 발생이 많았다〈Table 4〉.

\section{5. 외상 발생 시간의 분포}

외상의 발생은 하루 중 17 시에서 24 시 사이에 $57.9 \%$ 로 가장 많이 발생하였고, 9시에서 16 시 사이는 $26.2 \%$ 로 나타났다 $\langle$ Table 5$\rangle$.

\section{6. 외상치아의 치아별 위치 분포}

외상 치아의 치아별 위치 분포는 (유)중절치가 $56.5 \%$ 로 가장 많았고, 그 다음이 (유)측절치가 27.0\%로 나타났다〈Fig. 1〉.

Table 3. Causes of injuries according to dentition

Unit: $\mathrm{N}(\%)$

\begin{tabular}{ccccccc}
\hline \multirow{2}{*}{ Dentition } & \multicolumn{5}{c}{ Causes of injuries } \\
\cline { 2 - 7 } & Traffic accident & Fall down & Sports & Fight $\cdot$ & Others $^{*}$ & Total \\
\hline Primary & $7(16.7)$ & $20(47.6)$ & $0(0.0)$ & $0(0.0)$ & $15(35.7)$ & $42(100.0)$ \\
Permanent & $20(13.6)$ & $51(34.7)$ & $2(1.4)$ & $42(28.6)$ & $32(28.2)$ & $147(100.0)$ \\
\hline
\end{tabular}

Intact teeth are excluded

"Others include the collision

$\chi^{2}=11.605, \mathrm{p}<0.05, \quad \chi^{2}=36.486, \mathrm{p}<0.00$

Table 4. Causes of injuries according to position

Unit: $N(\%)$

\begin{tabular}{ccccccc}
\hline \multirow{2}{*}{ Position } & \multicolumn{5}{c}{ Causes of injuries } \\
\cline { 2 - 7 } & Traffic accident & Fall down & Sports & Fight & Others $^{*}$ & Total $^{*}$ \\
Maxilla & $23(14.7)$ & $60(38.5)$ & $2(0.8)$ & $35(22.4)$ & $36(23.1)$ & $156(100.0)$ \\
Mandible & $8(14.3)$ & $15(26.8)$ & $0(0.0)$ & $20(35.7)$ & $13(23.2)$ & $56(100.0)$ \\
\hline
\end{tabular}

"Others include the collision

$\chi^{2}=14.596, p<0.05, \quad \chi^{2}=19.110, p<0.05$ 
Table 5. Time of occurrence after injury

\begin{tabular}{lr}
\hline \multicolumn{1}{c}{ Time } & Patients \\
\hline $1 \sim 8 \mathrm{hr}$ & $39(15.5)$ \\
$9 \sim 16 \mathrm{hrs}$ & $66(26.2)$ \\
$17 \sim 24 \mathrm{hrs}$ & $146(57.9)$ \\
Unknown & $1(0.4)$ \\
Total & $252(100.0)$ \\
\hline
\end{tabular}

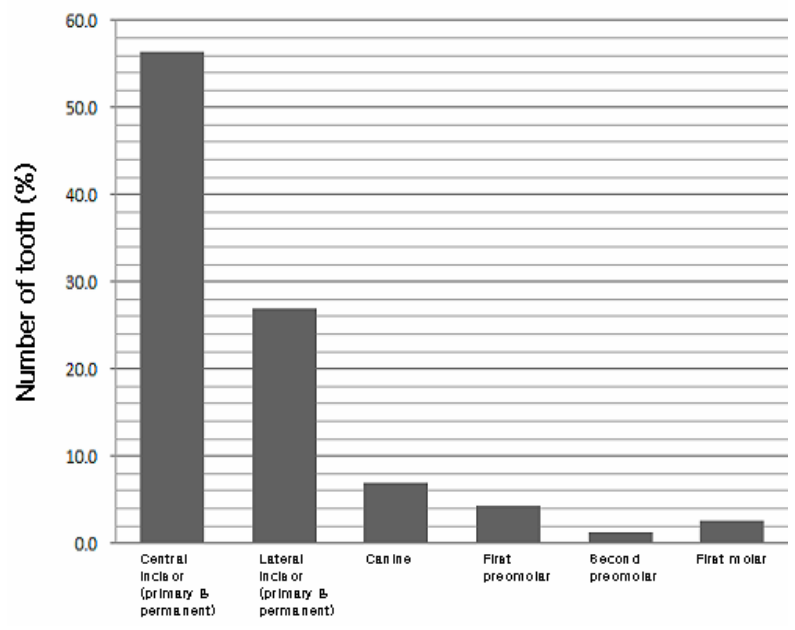

Fig. 1. Distribution of traumatic tooth

\section{7. 외상 시 손상 받은 치아의 개수}

구강악안면부 외상 발생 시 손상 받은 치아의 수에 대한 분포는 손상유형에 따라 통계적으로 유의한 차이가 있었다 $\left(\chi^{2}=264.714, \mathrm{p}<0.001\right)$. 외상 발생 시 치아손상은 1 개 인 경우 가 29.8\%로 가장 많았으나 치아 손상이 없는 경우도 $26.6 \%$ 나 되었다. 그리고 치아 손상의 수와 관계없이 파절(fracture)이 $32.5 \%$ 로 가장 많았다 〈Table 6〉.

\section{8. 외상 시 동반손상 여부}

외상 시 동반손상이 있는 경우는 $33.7 \%$ 이었다. 그 중 구강
연조직 손상이 치조골 손상보다 비중이 컸으며, 그 중 치은 손상(10.7\%), 혀나 연구개 등 기타 연조직 손상(7.5\%), 소대 손상(6.0\%)이 대부분이었다〈Table 7$\rangle$.

Table 7. Types of soft tissue and hard tissue damage due to trauma

\begin{tabular}{llr}
\hline \multicolumn{1}{c}{ Area } & $\begin{array}{c}\text { Patient's } \\
\text { number }\end{array}$ \\
\hline & Upper lip & $9(3.6)$ \\
& Lower lip & $6(2.4)$ \\
Soft tissue & Frenum & $15(6.0)$ \\
& Gingiva & $27(10.7)$ \\
& Buccal mucosa & $4(1.6)$ \\
Hard tissue & Othera(tongue, soft palate) & $19(7.5)$ \\
(alveolar bone) & Maxilla & $1(0.4)$ \\
None & Mandible & $4(1.6)$ \\
Total & & $167(66.3)$ \\
\hline
\end{tabular}

\section{9. 치아외상의 유형}

구강악안면부 외상 발생 시 치열에 따른 손상 유형의 분포 는 손상유형에 따라 통계적으로 유의한 차이가 있었다(상악 $\chi^{2}=49.028, \mathrm{p}\left\langle 0.05\right.$, 하악 $\chi^{2}=139.363, \mathrm{p}\langle 0.05)$. 유치열의 경우 아탈구(subluxation)와 탈구(luxation)가 각각 $28.6 \%$ 으로 가 장 많았으며, 영구치의 경우 파절(fracture)이 $50.0 \%$ 로 가장 많은 비율을 차지하였다〈Table 8〉.

\section{총괄 및 고안}

$\mathrm{H}$ 병원은 2차 의료기관으로 주위 반경 $5 \mathrm{~km}$ 내에 800 병상 이상 규모의 대학 부속병원이 2곳 있으며 그 밖에 권역 응급 의료센터 1 곳, 지역 응급의료센터 4곳, 응급실을 운영하고 있는 종합병원 및 병원급의 지역응급의료기관 4곳 및 다수의 의원이 야간진료를 실시하고 있는 곳으로서 응급의료 시설이

Table 6 . The number of damaged teeth due to trauma

Unit: $N(\%)$

\begin{tabular}{lcccrrr}
\hline \multirow{2}{*}{ Number } & \multicolumn{5}{c}{ Types of injuries } \\
\cline { 2 - 6 } & Subluxation & Luxation & Avulsion & Concussion & Fracture & Total \\
\hline 0 & $0(0.0)$ & $0(0.0)$ & $0(0.0)$ & $0(0.0)$ & $0(0.0)$ & $67(26.6)$ \\
1 & $13(17.3)$ & $9(12.0)$ & $6(8.0)$ & $13(17.3)$ & $34(45.3)$ & $75(29.8)$ \\
2 & $7(15.6)$ & $7(15.6)$ & $5(11.1)$ & $7(15.6)$ & $19(42.2)$ & $45(17.9)$ \\
3 & $6(18.2)$ & $2(6.1)$ & $4(12.1)$ & $6(18.2)$ & $15(45.5)$ & $33(13.1)$ \\
4 & $4(21.1)$ & $2(10.5)$ & $2(10.5)$ & $3(15.8)$ & $8(42.1)$ & $19(7.5)$ \\
25 & $2(15.4)$ & $0(0.0)$ & $4(30.8)$ & $1(7.7)$ & $6(46.2)$ & $13(5.2)$ \\
Total & $32(12.7)$ & $20(7.9)$ & $21(8.3)$ & $30(11.9)$ & $82(32.5)$ & $252(100.0)$ \\
\hline
\end{tabular}

$\chi^{2}=264.714, p<0.00$ 
Table 8. Types of traumatic injuries of the teeth

Unit: $\mathrm{N}(\%)$

\begin{tabular}{lcccccc}
\hline \multirow{2}{*}{ Dentition } & \multicolumn{5}{c}{ Types of injuries } \\
\cline { 2 - 7 } & Subluxation & Luxation & Avulsion & Concussion & Fracture & Total \\
\hline *Primary & $12(28.6)$ & $12(28.6)$ & $4(9.5)$ & $3(7.1)$ & $9(21.4)$ & $40(100.0)$ \\
***.. & $22(15.1)$ & $8(5.5)$ & $17(11.6)$ & $26(17.8)$ & $73(50.0)$ & $146(100.0)$ \\
\hline
\end{tabular}

Intact teeth are excluded

$\chi^{2}=49.028, \mathrm{p}<0.05, \quad \chi^{2}=139.363, \mathrm{p}<0.05$

비교적 밀집되어 있는 곳에 위치하고 있다. 그러나 교통량의 증가와 청소년 유해환경 등 지역적인 특성으로 인하여 폭력 으로 인한 손상 및 교통사고로 인한 외상환자가 많이 내원하 고 있고, 인구밀집지역으로 인구의 고령화와 함께 각 종 성인 병 및 심혈관계 질환의 증가와 생활수준의 향상으로 의료 수요가 커짐으로써 응급실 내원환자가 꾸준히 증가하는 추세 에 있다. 2005년 치과가 별관으로 확장 이전하게 되면서 야간 응급실 내원환자 중 치과 응급환자에 대한 실태조사를 통해 향후 처치에 도움을 얻고자 이 연구를 진행하였다.

이번 연구 결과 외상환자의 경우 남녀 성비는 1.65:1로 남자 가 여자보다 많은 외상을 경험하는 것으로 나타났다. 특히 남자와 여자 모두 10세 이하에서 가장 높은 치아 외상 경험을 보였다. 유치열과 영구치열은 손상이 있는 경우만 본 결과 유치열보다는 영구치열에서 높은 외상발생을 보였다. 이것 은 아이들이 연령이 증가하면서 다양한 활동 및 운동이 외부 에서 이루어지면서 영구치열에서 외상이 증가하고, 또한 남 자가 여자에 비해 과격한 놀이와 운동 등의 활동량이 많기 때문으로 사료된다. Oikarinen 등ํㅡㄴ 의상을 많이 받는 나이 는 걸음마를 시작하지만 신체 구조간의 운동 기능 조화의 부족으로 스스로 방어할 수 없는 1.5 세에서 2.5 세 사이의 소 아와 바깥 활동이 증가하는 8 세에서 10 세 사이에서 빈번하게 일어나며, 이러한 외상은 치아의 많은 문제를 야기한다고 하 였다. 김과 이 ${ }^{11)}$ 의 연구에서는 특히, 외상성 손상을 경험한 아동들에게는 신체적, 정신적 측면에서 바람직하지 않은 영 향을 끼치는데 특히 저작, 발음 및 심미적인 문제 그리고 후속 영구치배와 악골의 발육에 대한 문제 등 아동의 삶의 질에 영향을 준다고 하였다. 허 등 ${ }^{12}$ 은 소아 및 청소년기에 발생 할 수 있는 외상에 대해 정확한 병력 청취와 진단 및 조속한 치료를 통해서 추후에 발생할 수 있는 합병증을 피하는 것이 필요하다고 하였다.

외상의 원인으로서 지역과 대상에 따라 다양한 차이는 있 으나 주요한 원인으로 실족이 주를 이루며 ${ }^{13,14)}$ 이외에도 물체 에 맞는 경우와 자전거나 스포츠에 의한 사고, 폭력, 교통사고 등이 보고되었다 ${ }^{15,16)}$. 본 연구에도 10 세 이하에서는 낙상 (51.8\%), 51세 이상에서도 낙상(53.8\%) 비율이 높았고 그 외 의 연령에서는 부딪힘과 싸움의 비율이 높았다. 유치열과 영
구치열기 모두 낙상의 비율이 높았으며, 상악에서는 낙상 (38.5\%), 하악에서는 싸움(35.7\%)에 의한 외상의 발생이 많았 다. 배와 황 ${ }^{17)}$ 은 어린이나 성인 모두에서 넘어짐에 대한 주의 가 필요하며, 특히 공공시설의 넘어짐에 대한 주의표시, 넘어 짐의 원인이 되는 모든 시설물에 대한 안전장치 및 보행자 스스로의 안전에 대한 인식이 필요하다고 하였다.

외상 발생 시간을 보면, 손과 김 ${ }^{18}$ 의 연구에서는 점심때에 손상을 입는 경우가 $52.9 \%$ 로 가장 많았다고 하였다 하지만 본 연구에서는 17 시에서 24 시 사이에 $57.9 \%$ 로 가장 많이 발 생하였고, 9시에서 16 시 사이는 $26.2 \%$ 로 나타났다. 이것은 부모 및 학교 선생님의 주의가 적은 방과 후 오후 시간대에 외상이 발생한 것으로 사료된다.

외상시 손상 받은 치아의 위치는 대부분의 연구에서 유치 및 영구치 모두에서 상악 중절치의 손상이 가장 많은 것으로 연구되었다 ${ }^{18,19)}$. 본 연구 또한 제 1 (유)중절치가 236 개(56.5\%) 로 가장 많았고, 그 다음이 제 2 (유)측절치가 113 개(27.0\%)로 나타나 다른 대부분의 연구들과 일치하였다. 이는 상악전치 의 악궁내에서 위치로 인해 외상에 노출이 가장 크기 때문이 명), 백 등 ${ }^{21)}$ 의 연구에서는 증가된 수평피개로 상악 전치부 가 돌출된 경우와 불완전 입술폐쇄를 가진 경우에서 상악 전치부 외상의 빈도가 더 증가한다고 하였다.

외상시 손상 받은 치아의 개수는 Schatz과 Joho ${ }^{22)}$ 는 1 개의 치아손상 $38 \%$ 로 가장 많았다고 하였고, Caliskan과 Türkünn ${ }^{23)}$ 은 1 개인 경우가 $60 \%$ 로 가장 높다고 하여 본 연구 결과와 일치하였다. 하지만 치아 손상이 없는 경우도 $26.6 \%$ 로 나타 났다. 이러한 차이는 진탕 등 경미한 증상이나 법랑질에만 한정된 파절을 포함하지 않은 경우가 많으며, 시간이 경과된 경우에는 증상이 나타나지 않을 수 있어서 결과에 차이가 있을 수 있다. 따라서 치아의 손상개수가 1 개나 2 개인 경우가 많지만 교통사고나 낙상으로 여러 개의 치아손상이 있을 수 있으므로 진단 시 누락되지 않도록 주의를 기울여 검사를 해야 하겠다.

의무기록지 조사 결과 치과 응급 환자의 주소는 외상이 가 장 많았고 두 번째로 치아 손상이었다. 타 의료기관의 조사 결과를 토대로 한 논문들을 살펴보면, 이 등 ${ }^{24}$ 은 응급실에 내원하는 악안면 영역의 문제로 외상(73.8\%)이 가장 많고, 
다음이 감염이라고 보고하였다. 김 등 25$)$ 은 외상(58.7\%)이 가 장 많았으며, 급성 치통, 출혈, 감염, 악관절 순이었다고 보고 하였으며, 외상환자는 연조직 손상, 치조골 손상, 치아 손상, 악골 골절의 순으로 나타났다. 금 등 ${ }^{20}$ 은 치아와 치조골 손상 은 치아 파절이 $59.6 \%$, 치아 아탈구 $14.9 \%$, 치아 완전 탈구 $13.9 \%$, 치아 진탕 $9.1 \%$, 치조골 파절이 $2.4 \%$ 로 보고하였다. 본 연구에서 외상 시 동반손상이 있는 경우는 $33.7 \%$ 이었다. 그 중 구강 연조직 손상이 치조골 손상보다 비중이 컸으며, 그 중 치은 손상 $(10.7 \%)$, 혀나 연구개 등 기타 연조직 손상 (7.5\%), 소대 손상(6.0\%)이었다. 유치열의 경우 아탈구 (subluxation)와 탈구(luxation)가 각각 28.6\%로 가장 많았으 며, 영구치의 경우 파절(fracture)이 $50.0 \%$ 로 비율이 높게 나 타났다. 본 연구 결과와 같이 Cardoso와 de Carvalho Rocha ${ }^{27}$ 는 영구치열기의 가장 흔한 손상이 치관파절이며, 유치열기 에는 탈구성 손상이 가장 흔하다고 하였다. 이러한 원인으로 는 유전치의 생리적 치근흡수와 연관이 있을 것이다. 정 등 ${ }^{28)}$ 은 연령이 증가하면서 유전치의 탈락과 함께 치조와로부터 쉽게 이탈되기 쉬우므로 여러 종류의 외상에 의한 정출성 손상이 일어날 가능성이 크다고 하였다.

유치에서 외상이 일어난 경우, 후속영구치의 외상이 부가 적으로 나타날 수 있다. Andreasen과 Ravin ${ }^{29)}$ 은 유전치 외상 병력이 있는 영구치 평가 시 41\%에서 발생장애를 보였으며 계승치의 $61 \%$ 에 장애를 나타낸다고 하였다. Riekman과 Badrawy ${ }^{30}$ 는 유전치 조기 상실과 언어 발달의 관계를 평가하 였는데, 장기적인 언어 발달에 대한 평가 시 영향을 미치지 않으나 발치 시기가 어릴수록 언어부조화의 경향이 크며, 남 자 어린이의 경우 언어부조화가 더 크다고 하였다. 모든 손상 에 대한 응급처치가 중요하지만 특히 완전 탈구된 치아는 손상 직후의 즉각적이고 적절한 응급처치 여하에 따라 그 예후가 지대한 영향을 받는다고 하였다. 손상은 사전에 예방 하는 것이 가장 중요하지만, 일단 발생하게 되면 양호한 예후 를 위한 적절한 응급처치가 필요하다고 하였다 ${ }^{31)}$. 그러므로 불량한 예후를 예방하기 위해서는 치아 외상 유형별 치료법 에 따른 예후 관찰 기간과 대상 치아수를 더 확보한 연구가 필요할 것으로 사료된다.

본 연구의 제한점으로는 1 개 병원으로 연구대상자를 선정 하였고, 연구대상의 표본크기가 작아 우리나라 전체 병원의 치아외상 실태를 대표하여 해석하기에는 무리가 있을 수 있 다. 따라서 현재 외상 환자 수가 증가하는 시점에서 추가적인 연구가 필요하며, 많은 연구를 통해서 치아 외상 예방법 및 처치에 관한 체계적인 관리가 가정과 학교 및 병원 등에서 이루어져야 할 것이다. $\mathrm{H}$ 병원 치과의 경우 이전하게 되면서 응급의료센터와 다른 건물에 위치하게 되어 환자의 동선이
길어짐으로 인해 진단의 지연과 이동에 따르는 환자의 불편 감 문제를 해결하기 위한 방안이 모색되어야 하며, 야간 응급 당직의 경우 초진 진료의사가 구강악안면외과 의사로서 구강 악안면외과 영역에 대한 초기 처치는 잘 이루어지는데 반해 치아의 응급치료를 간과하는 경우가 생길 우려가 있다. 따라 서 2년간 응급실에 내원한 치과 환자에 대한 조사를 통하여 외상 및 치아 외상 환자의 유형을 이해하고 적절한 진단과 처치를 위한 가이드라인을 마련하여 응급처치를 담당하는 의료진들이 앞으로 내원할 응급환자들에게 최선의 진료를 제공할 수 있도록 하고자 노력하는 것이 매우 중요하다고 사료된다.

\section{결론}

본 연구는 $\mathrm{H}$ 병원 응급실에 내원한 치과 환자에 대한 연구를 통하여 치과 외상 환자의 유형을 이해하며 적절한 진단과 처치에 도움을 얻고자 하는데 그 목적이 있다. 이를 위해

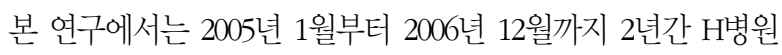
응급실에 내원한 환자 중 야간에 치과에서 응급진료를 받은 환자 252 명을 대상으로 선정하였다. 모든 대상자들의 내원 당시 의무기록지 내용과 임상소견을 기초로 하여 외상 환자 의 연령, 성별, 치열, 손상 원인, 손상 시기, 동반 손상 유무, 외상 시 손상 치아의 위치 및 개수, 손상 유형에 대한 검사를 시행하여 다음과 같은 결과를 얻었다.

1. 성별에 따른 발생빈도는 $1.65: 1$ 로(삭제) 남자의 비율이 높았고, 나이에 따른 발생빈도는 10 세 이하(43.7\%)가 가장 높았다.

2. 치아 손상의 원인 중 낙상으로 인한 치아손상이 105 개 (41.7\%)로 가장 높게 나타났고, 10세 이하에서는 $51.7 \%$ 로 가장 높았다.

3. 유치열과 영구치열 모두에서 낙상에 의한 외상의 발생 의 비율이 높았다

4. 외상의 발생은 하루 중 17 시에서 24 시 사이에 가장 많이 발생하는 것으로 나타났다.

5. 외상치아의 위치 분포는 제 1 (유)중절치와 제 2 (유)측절 치가 높게 나타났고, 외상 발생 시 치아손상은 1 개 인 경우가 $29.8 \%$ 로 가장 많았다.

6. 외상 시 동반손상이 있는 경우는 $33.7 \%$ 이며, 그 중 구강 연조직 손상이 치조골 손상보다 비중이 컸으며, 그 중 치은 손상 $(10.7 \%)$, 혀나 연구개 등 기타 연조직 손상 (7.5\%), 소대 손상(6.0\%)으로 나타났다.

7. 유치열의 경우 아탈구(subluxation)와 탈구(luxation)가 
각각 $28.6 \%$ 로 가장 높았고, 영구치의 경우 파절 (fracture)이 $50.0 \%$ 로 가장 높은 비율을 차지하였다.

치아외상의 다양한 원인과 양상을 이해하여 치아 외상 환 자의 치료에 대한 임상 지침이 제공되어야 할 것이다.

\section{References}

1. Andreasen FM, Andreasen JO. Treatment of traumatic dental injuries. Shift in strategy. Int J Technol Assess Health Care 1990; 6(4): 588-602. http://dx. doi.org/10.1017/S0266462300004232.

2. Todd JE, Dodd T. Children's dental health in the United Kingdom 1983. London: HMSO; 1985: 69-70.

3. Andreasen JO, Andreasen FM. Dental traumatology: quo vadis. Dental Traumatology 1990; 6(2): 78-80. http://dx.doi.org/ 10.1111/j.1600-9657.1990.tb00395.x

4. Ministry of health and welfare. 2010 Korean national oral health survey. Seoul: Ministry of health and welfare; 2011: 328-9.

5. Ministry of health and welfare. 2003 Korean national oral health survey. Seoul: Ministry of health and welfare; 2004: 29-30.

6. Ministry of health and welfare. 2006 Korean national oral health survey. Seoul: Ministry of health and welfare; 2007: 102.

7. Lim SS. Clinical endodontics. 3rd ed. Seoul: Dental and Medical Publishing Co; 2007: 295-320.

8. Baik JS, Yoon KH, Park KS, Cheong JW, Shin JM, Choi MH, et al. A clinical study on the emergency patients of oral and maxillofacial surgery visiting Sang-Gye Paik Hospital emergency room. J Korean Assoc Maxillofac Plast Reconstr Surg 2008; 30(6): $561-6$.

9. Petersson EE, Andersson L, Sörensen S. Traumatic oral vs non-oral injuries. Swed Dent J 1997; 21(1-2): 55-68.

10. Oikarinen K, Gundlach KK, Pfeifer G. Late complications of luxation injuries to teeth. Endod Dent Traumatol 1987; 3(6): 296-303. http://dx.doi.org/10.1111/j.1600-9657.1987.tb00638.x

11. Kim DW, Lee KS. A study on the traumatic injury of patients in department of pediatric dentistry, Kangnung national university dental hospital. J Korean Acad Pediatr Dent 2001; 28(2): 247-54.

12. Heo SK, Choi NK, Kim SM, Yang KH, Park J. A retrospective study of the traumatic injuries in the primary and permanent teeth. J Korean Acad Pediatr Dent 2008; 35(4): 642-51.

13. Oluwole TO, Leverett DH. Clinical and epidemiological survey of adolescents with crown fractures of permanent anterior teeth. Pediatr Dent 1986; 8(3): 221-5.

14. Uji T, Teramoto T. Occurrence of traumatic injuries in the oromaxillary region of children in a Japanese prefecture. Endod Dent Traumatol 1988; 4(2): 63-9. http://dx.doi.org/10.1111/ j.1600-9657.1988.tb00296.x
15. Caldas AF Jr, Burgos ME. A retrospective study of traumatic dental injuries in a Brazilian dental trauma clinic. Dent Traumatol 2001; 17(6): 250-3. http://dx.doi.org/10.1034/ j.1600-9657.2001.170602.x

16. Oikarinen K, Kassila O. Causes and types of traumatic tooth injuries treated in a public dental health clinic. Endod Dent Traumatol 1987; 3(4): 172-7. http://dx. doi.org/10.1111/j .1600-9657.1987.tb00620.x

17. Hwang SJ, Bae SS. Evaluation of etiological factors for injuries at oral and maxillofacial area. J Dent Hyg Sci 2012; 12(4): 310-9.

18. Sohn HK, Kim OK. A study of dental trauma in children. J Korean Acad Pediatr Dent 1990; 17(1): 173-88.

19. Gábris K, Tarján I, Rózsa N. Dental trauma in children presenting for treatment at the department of dentistry for children and orthodontics, Budapest, 1985-1999. Dent Traumatol 2001; 17(3): 103-8. http://dx. doi.org/10.1034/ j.1600-9657.2001.017003103.x

20. Ekanayake L, Perera M. Pattern of traumatic dental injuries in children attending the University Dental Hospital. Sri Lanka. Dent Traumatol 2008; 24(4): 471-4. http://dx. doi.org/10.1111/ j.1600-9657.2008.00611.x.

21. Baik BJ, Yang YM, Yang CH, Kim JG. An investigation of traumatic dental injuries in children. Korean Acad Pediatr Dent 2001; 28(4): 600-12

22. Schatz JP, Joho JP. A retrospective study of dento-alveolar injuries. Endod Dent Traumatol 1994; 10(1): 11-4. http://dx. doi.org/10.1111/j.1600-9657.1994.tb00591.x

23. Calişkan MK, Türkün M. Clinical investigation of traumatic injuries of permanent incisors in Izmir, Turkey. Endod Dent Traumatol 1995; 11(5): 210-3.

24. Lee DK, Min SK. Yang CY, Mun C, Kim JG. A clinical study of the dental emergency patients visiting Wonkwang Univ Hospital emergency room. Korean Assoc Maxillofac Plast Reconstr Surg 2004; 24(1): 31-9.

25. Kim SH, Kim DY, Baek JS, Jung TY, Park SJ. Characteristics of dental emergency patients at busan Paik Hospital. Korean Assoc Maxillofac Plast Reconstr Surg 2012; 34(1): 58-64.

26. Keum KC, Paeng JY, Choi BY, Choi JU, Oh SR, Lee J, et al. An clinical analysis on the dental emergency patients visiting the emergency room of dental hospital of Won-Kwang University. J Korean Assoc Maxillofac Plast Reconstr Surg 2009; 31(1): 35-40.

27. Cardoso M, de Carvalho Rocha MJ. Traumatized primary teeth in children assisted at the Federal University of Santa Catarina, Brazil. Dent Traumatol 2002; 18(3): 129-33. http://dx.doi.org/10.1034/j.1600-9657.2002.00030.x

28. Chung YJ, Kim KC, Park JH, Choi SC. A study on the traumatic injuries to primary teeth. Korean Acad Pediatr Dent 2010; 37(3): 
328-37.

29. Andreasen JO, Ravin JJ. Enamel changes in permanent teeth after trauma to their primary predecessors. Scand J Dent Res 1973; 81(3): 203-9. http://dx.doi.org/10.1111/j.1600-0722.1973. tb00330. $x$

30. Riekman GA, el Badrawy HE. Effect of premature loss of primary maxillary incisors on speech. Pediatr Dent 1985; 7(2): $119-22$.

31. Kim SJ, Kim WJ, Lee BJ. Cognition of 119 emergency medical technicians on dental emergency treatment in the Jeju province. J Korean Acad Dent Health 2012; 36(2): 131-6. 